\title{
Gender Differences in Mental Health Responses of Health Workers During the Covid-19 Pandemic: A Systematic Review with Meta-Analysis
}

\author{
Riyesti Hero Fresna1), Shinta Nur Atikah), Muna Maimunah Salsabila3), Pringga Widya \\ Pusparini4), Ratih Hermas Purnasari5), Riski Anisa'), Feny Oktaviyani7), Ruliany Yuni Nurul \\ Hakim ${ }^{8)}$, Muhammad Husein Syawaludin9), Syndia Puspitasari' ${ }^{10)}$ \\ 1)Purwantoro Special Educational School, Wonogiri, Ccentral Java \\ 2)Center for Environmental Health Engineering and Disease Control, Yogyakarta \\ 3)Universitas Sebelas Maret, Surakarta \\ 4)Beautylogica Clinic, Surakarta, Central Java \\ 5)Ngudi Waluyo University, Semarang, Central Java \\ 6) Jember University, East Java \\ 7)Academy of Physiotherapy, Dustira Cimahi Hospital, West Java \\ 8) Jasa Kartini Hospital, Tasikmalaya, West Java \\ ${ }^{9)}$ Husein Therapy Family, Surakarta, Central Java \\ 10)Simpang Lima Gumul Kediri Hospital
}

\section{ABSTRACT}

Background: The Covid-19 pandemic caused great stress, especially for health workers which resulted in moderate or severe symptoms of depression, anxiety, insomnia, and more serious stress. Gender is very influential, given the differences in biological and social roles between men and women. Gender differences between men and women allow for variations in strategies in responding to mental health to increase awareness and self-management, so as to avoid mental health problems during the Covid-19 pandemic.

Subjects and Method: Meta-analysis was performed by searching articles from Google Scholar, PubMed, Scopus, Springer Link, and health-related databases. The keywords used in the article search were "health workers" AND "covid-19" AND "mental health". The inclusion of the criteria in this study is a full text article, from 2019-2021, with astudy design cross- sectional. The article analysis was carried out using RevMan 5.3.

Results: There were 5 articles analyzed, the results showed no significant difference between gender and mental health responses among health workers during the Covid-19 pandemic $(\mathrm{aOR}=1.12 ; 95 \% \mathrm{CI}=0.59-2.13$; $\mathrm{p}=0.01$ ).

Conclusion: Not significant between primary studies regarding gender differences in mental health responses to health workers during the Covid-19 pandemic.

Keywords: health workers, covid-19, mental health

\section{Correspondence:}

Riyesti Hero Fresna, Purwantoro Special Educational School. Wonogiri Regency, Central Java 57695. E-mail: riyestiherofresnao1@gmail.com. Mobile +6281227831443 .

Cite this as:

Fresna RH, Atikah SN, Salsabila MM, Pusparini PW, Purnasari RH, Anisa R, Oktaviyani F, Hakim RYN, Syawaludin MH, Puspitasari S (2021). Gender Differences in Mental Health Responses of Health Workers During the Covid-19 Pandemic: A Systematic Review with Meta-Analysis. J Health Policy Manage. 06(02): 130-138. https://doi.org/10.26911/thejhpm.2021.06.02.05

cc (i) (2) Journal of Health Policy and Management is licensed under a Creative Commons Attribution-NonCommercial-ShareAlike 4.o International License.

\section{BACKGROUND}

Corona Virus Disease is an infectious disease caused by a newly discovered coro- navirusfirst appeared and was detected in Wuhan, China in December 2019. The cause is a new type of coronavirus, also 
known as the novel 2019 coronavirus (2019-nCoV). On March 9, 2020, WHO (World Health Organization) announced the COVID-19 virus as a global pandemic because it has spread widely in the world. In Indonesia, the National Disaster Management Agency on March 142020 has also designated the Corona Virus or Covid-19 Outbreak as a National Disaster.

The increase in the number of confirmed cases and the increase in the number of deaths due to COVID-19 are the main challenges facing the local health care system. As the number of COVID-19 patients increases, there will be more health resources, including health workers, beds and facilities. Limited resources cause great pressure and distress, especially health workers, this makes nurses more likely to be exposed to infection because they directly care for patients plus hours of service or work longer than before the outbreak (Lai et al., 2020). In addition to the risk factors for infection, less and less standard personal protective equipment (PPE), more work load, social discrimination, depression, maintaining distance and isolation so that there is less contact with family and fatigue (Kang et al., 2020). Other studies have shown that the COVID-19 pandemic results in an increase in workload (Cai et al., 2020), high fatigue (Cao et al., 2020), a lack of positive support from family and friends (Kim and Choi, 2016) and stigmatization. of society faced by medical personnel (Khanal et al., 2020).

A survey in China at the start of the COVID-19 pandemic of 1257 medical staff in 34 hospitals found that $1 / 2$ of the respondents had mild depression and $1 / 3$ had insomnia, of which nearly $16 \%$ of nurses, female, worked at the forefront of handling Covid 19 who exhibitmoderate or severe symptoms of depression, anxiety, insomnia, and more serious distress (Lai et al., 2020). In addition, other studies have reported that medical personnel experience emotional, mental and work pressure as well as the negative impacts of the COVID19 pandemic such as increased anxiety, depression, post-traumatic stress, loneliness and helplessness (Xiang et al., 2020). Factors that cause stress for health workers include: workload, fear of being infected with Covid-19, the negative stigma of carrying the virus and being far from family (Handayani et al., 2020).

In general, gender refers to the biological differences between men and women, and gender refers to the social roles of men and women (Broughton DE et al, 2017). In response to the COVID-19 pandemic, gender and gender-specific factors were encouraged to be included in medical research (Spagnolo et al., 2020). Although the mechanisms of gender and genderbased influence are unclear, gender-related biology, gender-related psychological factors, and behavioral responses may interact with COVID-19 related outcomes (Walter et al., 2020). Men who report COVID-19 have higher vulnerability and mortality (Jin et al., 2020). As the COVID-19 epidemic develops, research on gender differences is gaining more and more attention. Recently, in a global study, there were very large gender differences in beliefs and behaviors related to COVID-19, suggesting that women are more likely to take the COVID19 epidemic seriously and take control measures (Galasso et al., 2020 ).

In order to increase the effectiveness of gender-based public health policies and achieve gender equality, gender-related analysis becomes ready, and it is important to respond to any outbreaks with evidence from previous outbreaks (Wenham et al., 2020).

A systematic study of gender issues in mental health responses by health workers 
Munawaroh et al./ The Effect of the Quality of Health Services with the Level of Patient Satisfaction

is needed to provide understanding and input on strategic policies to increase awareness and self-management, so as to avoid mental health problems during the Covid-19 pandemic.

\section{SUBJECTS AND METHOD}

\section{Study Design}

This was a systematic review and metaanalysis carried out by following the PRISMA flow chart. Meta-analysis is performed by searching for articles from electronic databases on Google Scholar, PubMed, Scopus, Springer Link, and others related to health. The keywords were "health workers" AND "covid-19" AND "mental health".

\section{Inclusion Criteria}

The inclusion criteria were complete articles published in English, adjusted odds ratio (aOR) results, articles conducted with astudy design cross-sectional, examined mental health related to gender (male and female) to health workers during the Covid19 pandemic.

\section{Exclusion Criteria}

Exclusion criteria were cross-sectional study, without gender (male and female) in health personnel, did not report AoR during the Covid-19 pandemic, and published from 2019-2020.

\section{Variable Operational Definition}

Article searches were carried out by considering the eligibility criteria defined using the PICO model. The population in this study were health workers with mental health responses during Covid-19 and nonCovid-19.

\section{Instrument of study}

This study used a systematic review and meta-analysis carried out by following the PRISMA flow diagrams.

\section{Data Analysis}

The data were analyzed using RevMan 5.3 to determine the effect size and research heterogeneity. The results of the metaanalysis data analysis are presented in the form of a forest plot.

\section{RESULTS}

There were 5 articles with 2 articles from China, 1 article from Europe, 1 article from Spain, and 1 article from Taiwan. The process of searching for articles is carried out by searching through the database according to the PRISMA flow diagram and can be seen in Figure 1.

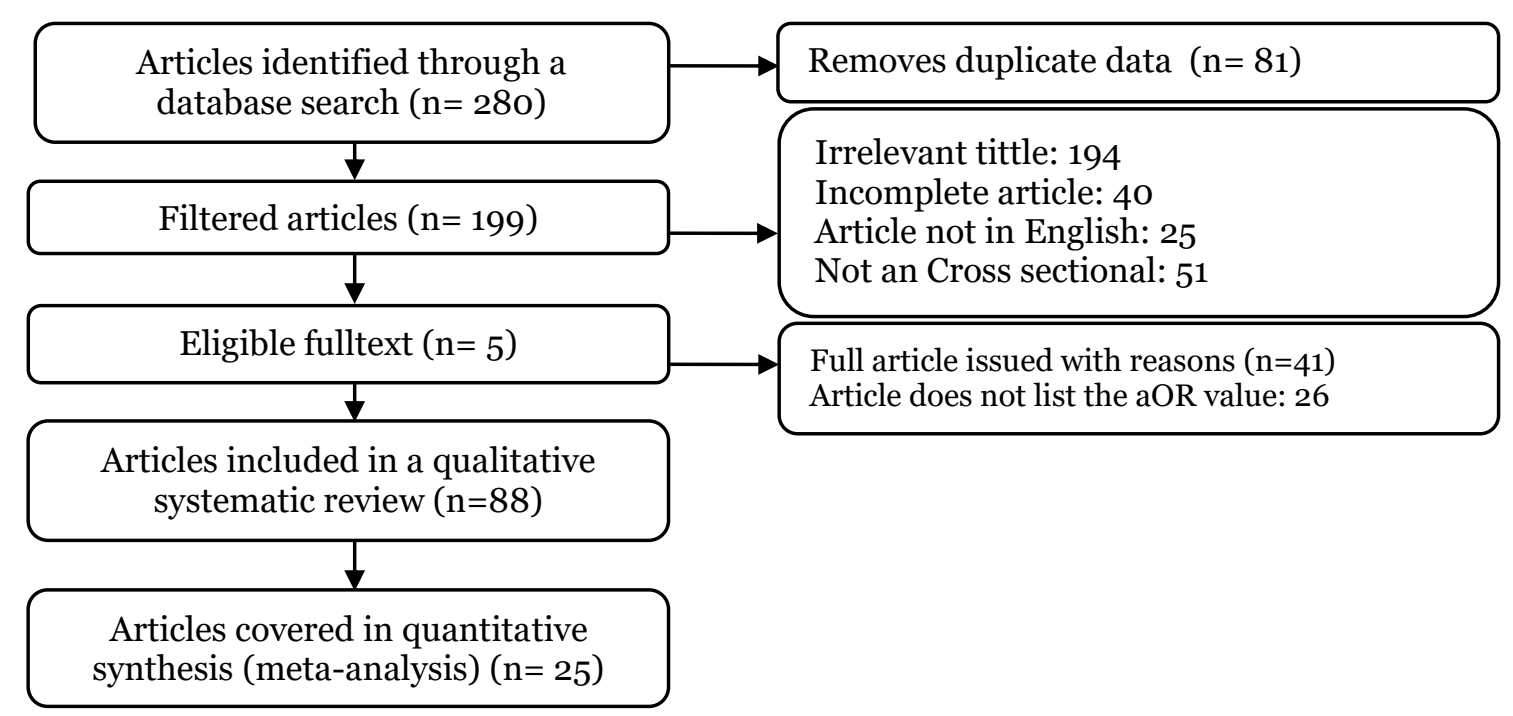

Figure 1. Diagram PRISMA flow chart 
Of a total of 280 articles there are 81 duplicates, articles are filtered to 199,194 irrelevant titles on-cross-sectional, 51 articles, articles There are 25 articles that are not in English, 40 articles that are not complete text, 5 complete and eligible articles, 41 complete articles

Table 1. Overview of primary studies on the risk of gender health workers having to experience mental health during the Covid-19 pandemic.

\begin{tabular}{|c|c|c|c|c|c|c|}
\hline $\begin{array}{c}\text { Author } \\
\text { (Year) }\end{array}$ & Title & Location & $\begin{array}{l}\text { Study } \\
\text { Design }\end{array}$ & $\begin{array}{c}\text { Population and } \\
\text { Sample }\end{array}$ & $\begin{array}{l}\text { Intervention } \\
\text { and } \\
\text { Comparison }\end{array}$ & Outcome \\
\hline $\begin{array}{l}\text { Cao et } \\
\text { al, } \\
2021\end{array}$ & $\begin{array}{l}\text { A cross-sectional study of psy- } \\
\text { chological status in different } \\
\text { epidemic areas in China after } \\
\text { the COVID-19 Outbreak }\end{array}$ & China & $\begin{array}{l}\text { Cross- } \\
\text { sectional }\end{array}$ & $\begin{array}{l}394 \text { women and } \\
86 \text { men are health } \\
\text { worker }\end{array}$ & $\begin{array}{l}\text { I: Women C: } \\
\text { Men }\end{array}$ & $\begin{array}{l}\text { Health care workers in Hubei had } \\
\text { higher levels of anxiety and depress- } \\
\text { ion than non-health care workers, no } \\
\text { correlation between man and women }\end{array}$ \\
\hline $\begin{array}{l}\text { Chen et } \\
\text { al, } \\
2021\end{array}$ & $\begin{array}{l}\text { Experience of } 2003 \text { SARS has a } \\
\text { negative psychological impact } \\
\text { on healthcare workers in the } \\
\text { Covid-19 pandemic: a cross- } \\
\text { Sectional study }\end{array}$ & Taiwan & $\begin{array}{l}\text { Cross- } \\
\text { sectional }\end{array}$ & $\begin{array}{l}51 \text { men and } 441 \\
\text { women are health } \\
\text { workers }\end{array}$ & $\begin{array}{l}\text { I: Women C: } \\
\text { Men }\end{array}$ & $\begin{array}{l}\text { female healthcare workers reported } \\
\text { significantly higher stress levels than } \\
\text { males }(49.0 \pm 16.5 \text { versus } 43.5 \pm \\
13.7 ; P=0.0109\end{array}$ \\
\hline $\begin{array}{l}\text { Leira et } \\
\text { al, } \\
2021\end{array}$ & $\begin{array}{l}\text { Psychological impact of Covid- } \\
19 \text { pandemic and related vari- } \\
\text { ables: A cross-sectional study } \\
\text { in a sample of workers in a } \\
\text { Spanish tertiary hospital }\end{array}$ & Spain & $\begin{array}{l}\text { Cross- } \\
\text { sectional }\end{array}$ & $\begin{array}{l}519 \text { women and } \\
138 \text { men are } \\
\text { health workers }\end{array}$ & $\begin{array}{l}\text { I: Women C: } \\
\text { Men }\end{array}$ & $\begin{array}{l}\text { the female gender appears to be a } \\
\text { variable significantly related to } \\
\text { positive screening in GHQ-12 (those } \\
\text { potentially with clinical disorders) }\end{array}$ \\
\hline $\begin{array}{l}\text { Liu et } \\
\text { al, } \\
2020\end{array}$ & $\begin{array}{l}\text { The prevalence and influencing } \\
\text { factors in anxiety in medical } \\
\text { workers fighting Covid-19 in } \\
\text { China: a cross-sectional survey }\end{array}$ & China & $\begin{array}{l}\text { Cross- } \\
\text { sectional }\end{array}$ & $\begin{array}{l}433 \text { women and } \\
79 \text { men are health } \\
\text { workers }\end{array}$ & $\begin{array}{l}\text { I: Women C: } \\
\text { Men }\end{array}$ & $\begin{array}{l}\text { staff with suspect infection cases } \\
\text { had higher anxiety scores than non- } \\
\text { suspect cases no correlation between } \\
\text { man and women }\end{array}$ \\
\hline $\begin{array}{l}\text { Ramire } \\
\text { z et al, } \\
2021\end{array}$ & $\begin{array}{l}\text { Impact of Covid-19 on the } \\
\text { anxiety perceived by healthcare } \\
\text { professionals: Differences } \\
\text { between primary care and } \\
\text { hospital care }\end{array}$ & Europe & $\begin{array}{l}\text { Cross- } \\
\text { sectional }\end{array}$ & $\begin{array}{l}264 \text { women and } \\
79 \text { men are health } \\
\text { workers }\end{array}$ & $\begin{array}{l}\text { I: Women C: } \\
\text { Men }\end{array}$ & $\begin{array}{l}\text { the variables "female" and "nurse" } \\
\text { Showed a greater level of anxiety } \\
\text { (7.6\% as Compared to man } 2.6 \%)\end{array}$ \\
\hline
\end{tabular}

but published on the grounds that there are 41, articles without aOR are 26, articles included in the qualitative systematic review are 88, There are 25 articles included in the quantitative systematic review. 


\section{Forest Plot}

Interpretation of the primary results from the meta-analysis study on figure 2, it was found that the gender risk of health workers had 1.12 times the risk of experiencing mental health during the Covid-19 pandemic compared to health workers based on gender non-Covid-19 pandemic.

\section{Funnel Plot}

Interpretation of the primary results from the meta-analysis study on figure 3, it was found that the funnel showed no publication bias as evidenced by the number of 2 plots on the left side and 3 plots on the right side that were balanced, and the distance between the plots was symmetric.

\begin{tabular}{|c|c|c|c|c|}
\hline Study or Subgroup & Iog[Odds Ratio] & SE & Weight & $\begin{array}{c}\text { Odds Ratio } \\
\text { IV, Random, } 95 \% \mathrm{Cl}\end{array}$ \\
\hline Cao 2021 & 0.2263 & 0.5173 & $17.4 \%$ & $1.25[0.45,3.46]$ \\
\hline Chen 2021 & -0.417 & 0.4084 & $20.8 \%$ & $0.66[0.30,1.47]$ \\
\hline Leire 2021 & 0.5516 & 0.2634 & $25.6 \%$ & $1.74[1.04,2.91]$ \\
\hline Liu 2020 & -1.3471 & 0.6695 & $13.5 \%$ & $0.26[0.07,0.97]$ \\
\hline Ramirez 2021 & 0.8755 & 0.3537 & $22.6 \%$ & $2.40[1.20,4.80]$ \\
\hline Total $(95 \% \mathrm{Cl})$ & & & $100.0 \%$ & $1.12[0.59,2.13]$ \\
\hline
\end{tabular}

\section{Figure 2. Forest Plot}




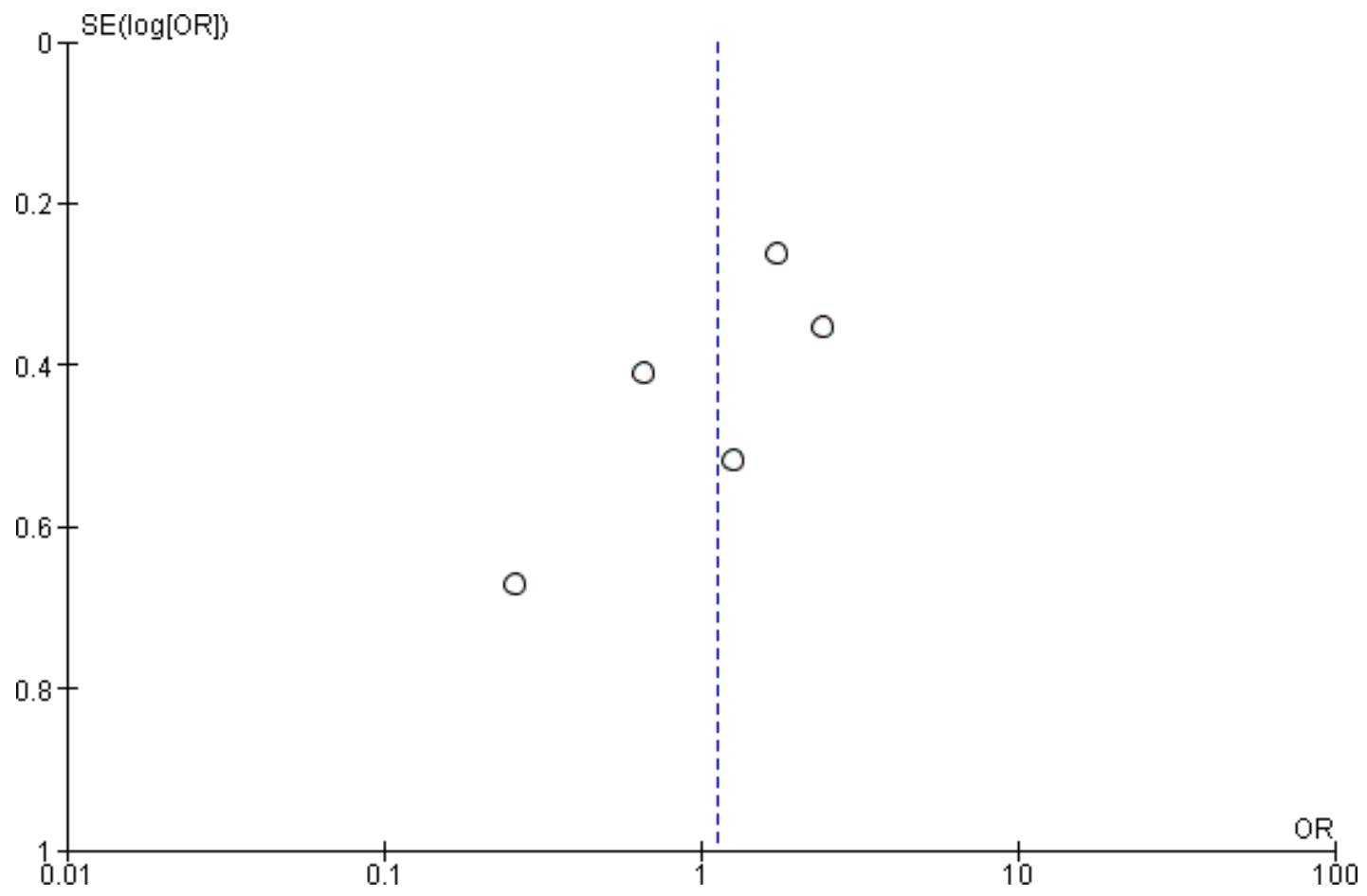

Figure 3. Funnel Plot

\section{DISCUSSION}

Corona Virus Disease is an infectious disease caused by a newly discovered type of coronavirus that first appeared and detected in Wuhan, China in December 2019. The cause is a new type of coronavirus or also known as the novel coronavirus 2019 (2019-nCoV). On March 9, 2020, the WHO (World officially Health Organization) announced the COVID-19 virus as a global pandemic because it has spread widely in the world.

A survey in China at the start of the COVID-19 pandemic of 1257 medical staff in 34 hospitals found that $1 / 2$ of the respondents had mild depression and $1 / 3$ had insomnia, of which nearly $16 \%$ of nurses, female, worked at the forefront of handling Covid 19 who exhibit moderate or severe symptoms of depression, anxiety, insomnia, and more serious distress (Lai et al., 2020).

In accordance with the study of Cao et al, 2020 with a population consisting of 394 women and 86 men who are health workers, showing that health workers in Hubei have higher levels of anxiety and depression than non-health workers, there is no correlation between men and women. A study by Chen et al, 2021 with a population consisting of 51 men and 441 health workers, showed that female health workers reported significantly higher levels of stress than men $(49.0 \pm 16.5$ versus $43.5 \pm 13,7 ; \mathrm{P}=$ 0.0109. In the study of Leira et al., 2021, it was clear that female gender appeared to be a variable significantly associated with positive screening in GHQ-12 (potentially associated with clinical impairment). This waslater reaffirmed in Chen's study. -Yun Liu et al, 2020 stated that staff with infected cases have a higher anxiety score than noninfected caseswhere there is no correlation between men and women. Greater degree of anxiety ( $7.6 \%$ versus $2.6 \%$ males).

The systematic review and meta-analysis in this study were carried out with the aim of studying and estimating the magni- 
tude of the effect of gender risk on mental health responses in health workers during the Covid-19 pandemic from various similar studies. In this study, the systematic review and meta-analysis used can be seen from the factors of the inclusion requirements of the study, namely complete articles published in English, articles conducted with a study design cross-sectional, articles examining mental health related to gender (male and women) during the Covid-19 pandemic, the results reported were the adjusted odds ratio (aOR) results.

The results of the systematic review and meta-analysis are presented in the form of a forest plot and a funnel plot. The forest plot in the meta-analysis results shows whether there is variation in heterogeneity. The funnel plot in the meta-analysis results shows whether there is a bias between the effect size of the study and the sample size of various studies that can be measured in different ways (Murti, 2016).

The funnel plot shows the effect size on the sample size, the funnel plot can be used to determine whether there is publication bias from the results of a meta-analysis study of a combination of several major studies. If the number of plot points on the left and right sides is not balanced, and the distance between the plots is far away indicates that there is publication bias. Conversely, if the number of plot points on the left and right sides is balanced, and the distance between the plots is not far, it indicates that there is no publication bias. There are 5 studies related to the effects of gender risk on mental responseshealth in health workers during the Covid-19 pandemic, including 2 articles from China, 1 article from Europe, 1 article from Spain, and 1 article from Taiwan.

Based on the results of the above research, it shows that there is heterogeneity in the risk of gender among health workers having to experience mental health during the Covid-19 pandemic $\left(\mathrm{I}^{2}=69 \% ; \mathrm{p}=\right.$ o.01). Interpretation of the primary results from the forest plot in a meta-analysis study, it was found that the gender risk for health workers had $\mathbf{1 . 1 2}$ times the risk of experiencing mental health during the Covid-19 pandemic compared to health workers based on gender non-Covid-19 pandemic. Then, the interpretation of the primary results from the funnel plot in the meta-analysis study, it was found that the funnel showed no publication bias as evidenced by the balance of 2 plots on the left and 3 on the right side of the plot, as well as the distance between the plots symmetrically.

\section{AUTHOR CONTRIBUTION}

Riyesti Hero Fresna and Shinta Nur Atikah contributed to data processing and analysis. Feny Oktaviyani, Muhammad Husein S, Muna Maimunah S contributed in interpreting and writing articles. Prigga Widya P, Ratih Hermas P, Riski Anisa, Ruliany Yuni. N. H, Syndia Puspitasari contributed to finding and sorting articles that will be used in the research.

\section{CONFLICT OF INTEREST}

There was no conflict of interest in this study.

\section{FUNDING AND SPONSORSHIP}

This study was not funded.

\section{ACKNOWLEDGEMENT}

We are very grateful to the provider databases, namely Google Scholar, Pubmed, Scopus, Springer Link, and databases related to health.

\section{REFERENCE}

Broughton DE, Brannigan RE, Omurtag KR (2017). Sex and gender: you should 
Munawaroh et al./ The Effect of the Quality of Health Services with the Level of Patient Satisfaction

know the difference. Sterile Fertile. 107 (6): 1294-1295. doi: 10.1016/j.fertnstert.2017.04.012.

Cai H, Tu B, Ma J, Chen L, Fu L, Jiang Y, Zhuang Q (2020). Psychological impact and coping strategies of frontline medical staff in Hunan Between January and March 2020 during the outbreak of Coronavirus Disease 2019 (COVID-19) in Hubei, China. Medical Sci Monit. 26: e924171-1-e924171-16. https://dx.doi.org/10.12659\%2FMSM .924171.

Cao HZC, Li GHY, Li L, Huang S, Zhao J, Liu J, Jiang Y et al. (2021). A crosssectional study of psychological status in different epidemic areas in China after the COVID-19 outbreak. Front Psychiatry. 11: 575705. doi: 10.3389 / fpsyt.2020.575705.

Chen CH, Pei HY, Fang LK, I J. Y,Che YS (2021). Experience of 2003 SARS has a negative psychological impact on healthcare workers in the COVID-19 pandemic: a cross-sectional study. Sao Paulo Med J. https://doi.org/10.1590/1516-3180.2020.0516.R1.10122020.

Galasso V, Pons V, Profeta P, Becher M, Brouard S, Foucault M (2020). Gender differences in COVID-19 related attitudes and behavior: Evidence from a panel survey in eight OECD countries. Proceedings of the National Academy of Sciences of the United States of America. 117(44): 27285-91.

Handayani R, Kuntari S, Darmayanti A, Widiyanto A, Atmojo J (2020). Factors that cause stress for health workers and the public during the Covid-19 pandemic. Journal of Mental Nursing. 8(3): 353-360. https://jurnal.unimus.ac.id/index.php/JKJ/article/view/5990.
Jin JM, Bai P, He W, Wu F, Liu XF, Han DM, Liu S, Yang JK (2020). Gender differences in patients with COVID19: Focus on severity and mortality. Front Public Health, 8: 152. https://doi.org/10.3389/fpubh.2020.00152.

Kang L, Li Y, Hu S, ChenM, YangC, Yang BX, Wang Y et al. (2020). Themental health of medical workers in Wuhan, China dealing with the 2019 novel coronavirus. The Lancet Psychiatry. 7(3): e14. https://doi.org/10.1016/S2215- 0366 (20) 30047-X.

Kim JS, Choi JS (2016). Factors influencing emergency nurses' burnout during an outbreak of middle east respiratory syndrome coronavirus in Korea. Asian Nursing Res. 10(4): 295-299. https://doi.org/10.1016/j.anr.2016.10.002.

Khanal P, DevkotaN, Dahal M, Paudel K, Joshi D (2020). Mental health impacts among health workers during COVID-19 in a low resource setting: a cross-sectional survey from Nepal. Global Health. 16: 89 https://doi.org/10.1186/s12992-020-00621-Z.

Lai J, Ma S, Wang Y, Cai Z, Hu J, Wei N, $\mathrm{Wu} \mathrm{J}$ et al. (2020). Factors associated with mental health outcomes among health care workers exposed to coronavirus disease 2019. JAMA Network Open, 3(3): 1-12. https://doi.org/10.1001/jamanetworko pen.2020.3976.

Leira SM, Madoz GA, Ochoa ME, Ibanez A (2020). Psychological impact of COVID-19 pandemic and related variables: A cross-sectional study in a sample of workers in a Spanish Tertiary Hospital. Int J Environ Res Public Health. 18(7): 3608. https://doi.org/10.3390/ijerph18073608.

Liu CY, Yun ZY, Xiao MZ, Xinying X, Qing LD, Wen WZ, Andy SK (2020). The prevalence and influencing factors in anxiety in medical workers fighting 
Munawaroh et al./ The Effect of the Quality of Health Services with the Level of Patient Satisfaction

COVID-19 in China: a cross-sectional survey. J Epidemiol Infect. 148(e98): 1-7. https://doi.org/10.1017/So950268820001107.

Murti B (2016). Principles and methods of epidemiological research Karanganyar: Bintang Fajar Offset.

Ramirez LAC, Garcia PS, Bernabeu JP, Perez ME, Rodriguez MJ, Van DHCJ (2021). Impact of COVID-19 on the anxiety perceived by healthcare professionals: Differences between primary care and hospital care. Int $J$ Environ Res Public Health. 18: 3277. https://doi.org/10.3390/ijerph18063 277.

Spagnolo PA, Ramchandani VA, Schwandt ML, et al. (2016). Faah gene variation moderates stress response and symptom severity in patients with posttraumatic stress disorder and co- morbid alcohol dependence. Alcohol Clin Exp Res. 40(11): 2426-34. https://doi.org/10.1111/acer.13210.

Walter LA, McGregor AJ (2020). Sex- and gender-specific observations and implications for COVID-19. West $\mathrm{J}$ Emerg Med. 21(3): 507-509. https://dx.doi.org/10.5811\%2Fwestjem.2020. 4.47536.

Wenham C, Smith J, Morgan R (2020). COVID-19: the gendered impacts of the outbreak. Lancet. 395(10227): 846-848. https://doi.org/10.1016/S0140-6736(20)30526-2.

Xiang Y, Yang Y, Li W, Zhang L, Zhang Q, Cheung $\mathrm{T}, \mathrm{Ng} \mathrm{CH}$ (2020). Timely mental health care for the 2019 novel coronavirus outbreak is urgently needed. The Lancet Psychiatry. 0366 (20): 1-2. https://doi.org/10.1016/S2215- 0366 (20) 30046-8. 